\title{
CORPORATE CHALLENGES IN GREENHOUSE GAS REPORTING UNDER THE EUROPEAN UNION LOW CARBON ROADMAP
}

\author{
Selim Lika ${ }^{1}$, Nebojša Jeremic ${ }^{2}$ \\ ${ }^{1}$ Consulate General of Montenegro, New York, United States \\ ${ }^{2}$ Telekom Srbija a.d., Belgrade, Serbia
}

\begin{abstract}
:
Achieving the EU goals and pledges in reducing the greenhouse gases will be a major challenge for all the member countries and their private sectors. The long term goal of reducing emissions by 80 to $95 \%$ until 2050 with the 1990 baseline year will require all the players involved to do their share. Currently, the regulatory and market pressures are influencing companies to report and take actions when it comes to emissions. Still, in many cases, the whole process is done on a voluntary basis. Having in mind the source of emissions, private companies will have to be leaders in this process. With the introduction of a stricter regulatory framework, many corporations will face challenges in adapting to the change.
\end{abstract}

Climate change and greenhouse gas emissions are the most overarching problems that our society will face for the decades to come. Climate change, caused by the release of greenhouse gases, is arguably the biggest challenge to sustainable development. According to the International Panel on Climate Change Reference [1] if the current rate of emissions continues, it will result in irreversible environmental, social and economic consequences for European Union and the world as a whole.

Measuring greenhouse gas emissions is an essential first step towards managing them. Many countries are trying to work together to find a solution to a problem that is quite complex, how to continue the economic growth while reducing the effects on the environment to the point were we do not jeopardize the prospects of future generations.

According to leading environmental scientists, the only way forward is to transform our economies into low carbon ones. This transformation will require major adjustments to the current way of conducting business. The European Union, with its commitments to greenhouse gas reductions is acting as a leader in this process. Many experts within the EU debate that achieving the EU goals and pledges in reducing the greenhouse gas emissions will be a major challenge for most of the member states as well as their private sectors.

Namely, under the Kyoto Protocol, the original 15 member states of the EU committed to reducing their greenhouse gas emissions by 8 percent under a 1990 baseline by 2012 reference [2]. In 2009, the EU pledged to unilaterally reduce the greenhouse gas emissions $20 \%$ by 2020 using the 1990 as the baseline year. Furthermore, this pledge developed as the $20-20-20$ package, meaning that in addition to the $20 \%$ emissions reductions, a $20 \%$ share of renewable energy sources in gross final energy consumption along with a $20 \%$ improvement in energy efficiency will be achieved by 2020 reference [3]. In addition to this, a long term goal of reducing emissions by $80 \%$ to $95 \%$ until 2050 was also agreed with the 1990 baseline year.

The main guideline documents on how the EU should deliver the greenhouse gas reductions in line with the $80 \%$ to $95 \%$ goals and transform the economy into a low carbon one are set in the "White paper on Transportation", "Energy Efficiency Plan" and "The Roadmap for moving to a competitive low carbon economy in 2050" reference [4].
These documents provide a framework on were EU should be, but they do not clarify how the shift towards a competitive low carbon economy will affect the corporations in the EU as well as their way of conducting business. For corporations, greenhouse gas emissions are usually looked at as a risk management issue, whether formally acknowledged or not reference [5]. Reporting is usually done on a voluntary basis and corporations that decide to report use different protocols, making the comparability process more complicated.

According to Price Waterhouse Coopers, greenhouse gas reporting is being pushed in two ways, by regulatory and market pressures. These forces impact the corporations to measure, disclose and propose reductions of emissions reference [6].

The market pressures are led by corporations and their decisions to either start reporting due to consumer pressure, voluntary decisions to report, imposed reporting to their partners and reporting due to competition. Wal-Mart, as one of the largest supply chains, decided in July 2010 to give preference to vendors that report their greenhouse gas emissions. This decision attracted many companies to start the reporting process.

In addition to the market pressures, a number of policies and commitments have been put in place in order to ensure the reduction of emissions from particular sectors in the EU reference [16]. Both, the market and regulatory pressures impacted companies in the Balkans to start reporting and look for reduction possibilities in their plants.

Cement Company Novi Popovac declare that their plant is working below the current world norms of $\mathrm{CO}_{2}$ emissions. This was a great success, having in mind that the global cement industry in itself is a major emitter and contributes around 5\% towards anthropogenic $\mathrm{CO}_{2}$ emissions through the chemical process of producing clinker and the extensive use of energy. Global cement production grew from $594 \mathrm{Mt}$ in 1970 to 2284 Mt in 2005, with the vast majority of the growth occurring in developing countries, especially China. In 2005, China produced $1064 \mathrm{Mt}$ (47\% of world cement production), while India, Thailand, Brazil, Turkey, Indonesia, Iran, Egypt, Vietnam, and Saudi Arabia accounted for another $394 \mathrm{Mt}$ (17\%) reference [7].

Telenor's report on sustainable business operations for 2013, shows that they are the only company in telecommunication sector in Serbia that in 2010 implemented the environmental 
protection management system (IS014001 Standard) and the sole telecommunications operator in Serbia holding a certificate on successful implementation of the system reference [8]. The total power consumption of Telenor group in 2013 was 44,96 GWh, meaning a $9,9 \%$ increase in consumption compared to the previous year, which was the result of Company's growth. Owing to the introduction of energy efficient technologies, the average consumption of power per radio station in 2013 was reduced by $2.9 \%$ in comparison to 2012 amounting to 1069.25 KWh.

Delta Holding, as the largest company in Serbia, based on revenue earnings in 2009 , employing 6,000 people also prepared a report about reducing Greenhouse Gas Emissions. One of their company - Delta Automoto has promoted the environmentally friendly Honda Civic Hybrid in the Serbian market. All the marketing campaigns for this car model convey the message that protection of the environment should be given a lot more attention. Delta delivery trucks with environmentally acceptable engines do 200 delivery rounds per day, or 180,000 kilometers, which is 75 percent of the total distance for daily deliveries. This Delta holding data shows the extent to which these interventions will contribute to reducing $\mathrm{CO}_{2}$ emissions, see reference [9]. Delta farm also has a facility for exploiting biomass, remnants of livestock production, in energy purposes. Although this system of producing energy is based on burning biomass, it has been confirmed that the amount of $\mathrm{CO}_{2}$ emitted is smaller than the amount absorbed by plants in their vegetation periods.

Although there is no official greenhouse reports from GSP Beograd, some research about transport in Belgrade show interesting results. Urban transport system development and exploitation could present unique challenge and opportunity to contribute to achieving green house gases (GHG) emission reductions. Passenger cars, often with only a single occupant, dominate personal travel. For example, average occupancy of passenger cars in Belgrade is less than 2 (1.4-1.7 persons per car) and average occupancy of public transportation vehicles (buses) is about 90 passengers. This means that about 50 passenger cars would be needed to transport the number of passengers transported by one bus. The emission of CO for the same passenger kilometers using passenger car is 700 times greater than for the bus. Important issue is also the problem of spatial occupancy - parking space. Road transport per cent age share of $\mathrm{CO}_{2}$ emission from combustion in OECD countries in 2003 was $23 \%$ reference [10].

The shift toward a low carbon economy will require much more though from both the private as well as the public sector. In order to achieve the reductions, five sectors will have to change drastically their concept of operating. Electricity will play a key role in this process. Namely, the power sector will need to reduce the carbon intensity close to zero. By 2030 the reductions in this sector are planned to be $54 \%$ to $68 \%$ lower than they were in 1990, while by 2050 the reduction would be 93\% to $99 \%$ lower than they were in 1990 reference [4]. Such a shift will most probably result in higher electricity prices, meaning higher operational expenses for the private sector or subsidies by Government.

The industry sector will also have to face major reductions in $\mathrm{CO}_{2}$ emissions, since according to the Roadmap the reduction by 2030 would be in the range from $34 \%$ to $40 \%$ while by 2050 in the range from $83 \%$ to $87 \%$ compared to the 1990 emissions. It is important to add that the EU already reduced the emissions related to this sector in 2005 by $20 \%$ compared to 1990 reference [4].

Emissions from the transportation sector will be a major challenge for both the private as well as public sector. According to available data, there was a $30 \%$ increase in emissions from transportation in 2005 compared to the baseline year 1990 ref- erence [16]. The goal set by the EU is to reduce the emissions in the range from $54 \%$ to $67 \%$ by 2050 compared to the 1990 baseline year. According to the current strategies, the $\mathrm{CO}_{2}$ emissions in this sector include the aviation emissions but they do not include the maritime emissions which are registering a continues growth.

The impact on the building sector will be a major one too. According to the EU Roadmap on low carbon development, an 88 to $91 \%$ decrease in emissions needs to be achieved by 2050 compared to the baseline year. In the first stage, wide implementation of energy efficiency measures will be of crucial importance. This will be complimented by stricter building codes. Furthermore, the Roadmap indicates that in order to achieve the $88 \%$ reduction target, the new buildings after 2020 need to be close to zero energy buildings. The EU did achieve a $12 \%$ reduction in 2005 , which gives hope for future reductions. Achieving this goal will require immediate action not only for the EU countries but also for countries that are in the accession process. Serbia in this case needs to start harvesting the lowlying fruits by implementing nationwide energy efficiency in the building sector.

For the agriculture, the reductions should be in the range from $42 \%$ to $49 \%$ until 2050 , while by 2030 these emission reductions need to be in the range from $36 \%$ to $37 \%$ reference [4]. The EU did already achieve $20 \%$ reductions in 2005 compared to the baseline year, but having in mind many factors that complicate the process of emission reductions in this sector, achieving these reductions will be a major challenge. Research in newest EU member show that all the electrical energy produced from biogas can replace and decrease the production of electrical energy for the national grid. According to reference [13] if all biogas potential of family farms would be utilized 343 GWh of electrical energy could be produced what matches the emission of 112504 tons. The things that have a bright future in Serbia and Montenegro are big bio farms and GMO free enterprises which need to be stimulated more strongly. That means existing farms in Serbia and Montenegro that also have biogas potential but also future farms that are going to be build in the future period. Both legal and financial, those farms needs to be stimulated to be a biogas producers, not only because of the energy they can produce or converse but because the fact that biogas production effectively deals with manure issues and manure management on farms in general.

In addition to all the mentioned sectors, the other non $\mathrm{CO}_{2}$ emissions need to be reduced as well. By 2050 these reductions need to be in the range from $70 \%$ to $78 \%$ while by 2030 they should be in the range from $72 \%$ to $73 \%$ compared to the baseline year. Until 2005, a 30\% reduction was already registered. Responsibilities and directives established with the aim to reduce the global warming are on one hand, and on the other is the responsibility of the companies and their risk management also in the attempt to find the way to reduce the emission of the green house gases effect maintaining the satisfactory productivity.

\section{CONCLUSIONS}

Achieving the EU goals and pledges in reducing the greenhouse gases will be a major challenge for all the member countries and their private sectors. The long term goal of reducing emissions by $80 \%$ to $95 \%$ until 2050 with the 1990 baseline year will require all the players involved to do their share. Currently, the regulatory and market pressures are influencing companies to report and take actions when it comes to emissions. Still, in many cases, the whole process is done on a voluntary basis. Having in mind the source of emissions, private companies will have to leaders in this process. With the introduction of a stricter regulatory framework, many corporations will face chal- 
lenges in adapting to the change. Managing risk to reputation is about fundamental perceptions of the company's contributions, value and strategic direction. Balkan countries are far away from good ecological risk management, but baby steps are made. In developed EU and OECD countries consumers can even find model for point-of-purchase comparisons: www.goodguide. com, which aggregates more than 200 such databases to rate companies and products on environmental, health, and social impacts. These include not just the greenhouse gas outputs of the company but also dozens of registries of "chemicals of concern" like BPA and phthalates (both of which are on the recent list announced by the EPA of industrial chemicals that will no longer be allowed in consumer products). From the findings, it is to be expected that the diversity in reporting will have to be dealt with on a regulatory level by requiring same reporting forms across EU. Companies that already produce a clean and comparable emission report will have a competitive advantage in case that a new regulatory framework is set in place or a new carbon tax is introduced. Furthermore, these companies will be able to identify possibilities for emission reductions and harvest the low-lying fruit, while positioning themselves as leaders. Having in mind the emission reduction goals of the EU, it is to be expected that in the near future environmental reporting will be of equal importance to companies and stakeholders as financial reporting and the environmental performance of a company will impact their overall success in the future carbon constrained economy.

\section{REFERENCES}

[1] IPCC (2013) "Climate Change 2013: The Physical Science Basis"

[2] United Nations (1998) "Kyoto Protocol to the United Nations Framework Convention on Climate Change"

[3] World Resources Institute (November 2012) " GHG mitigation in the EU: An overview of the current policy landscape"
[4] European Commission (March 2011.) "EU low carbon roadmap - A roadmap for moving to a competitive low carbon economy in $2050^{\prime \prime}$

[5] New Zeland Business Council for Sustainable Development (2002) "The challenge of greenhouse gas emissions"

[6] PWC (2010) "A framework for greenhouse gas reporting"

[7] Stefanović GM, Vučković GD, Stojiljković MM, Trifunović MB. CO2 reduction options in cement industry: The Novi Popovac case. Thermal Science. 2010; 14(3): pp. 671-679.

[8] Telenor Foundation, Report on sustainable business operations 2013, p. 22

[9] Delta holding report on sustainable business operations available on corporate site http://www.deltaholding.rs/social_responsibility/environment.93.html access 03.11.2014.

[10] Jović JJ, Đorić VD. Application of transport demand modeling in pollution estimation of a street network. Thermal Science. 2009; 13(3): p. 229

[11] Federal Ministry of Economics and Technology (2008) "Energy Concept for an Environmentally Sound, Reliable and Affordable Energy Supply"

[12] European Commission (March 2011.) "EU low carbon roadmap - A roadmap for moving to a competitive low carbon economy in 2050. “.

[13] T. PUKŠEC et. al., Biogas Potential in Croatian Forming Sector Strojarstvo 52 (4) 441-448, Veterinary Archives, p. 447.

[14] World Resources Institute (November 2012) “ GHG mitigation in the EU: An overview of the current policy landscape"

[15] CE Delft (2009) "Technical support for European action to reducing Greenhouse Gas Emissions from international maritime transport"

[16] AEA (2011) "Reduction and Testing of Greenhouse Gas (GHG) Emissions from Heavy Duty Vehicles - Final Report to the European Commission"

[17] Harvard Business review, Why Investors Should Consider Sustainability Risk Management, by Daniel Goleman, October 26, 2009

\title{
IZAZOVI KOMPANIJA U IMPLEMENTACIJI EKOLOŠKOG IZVEŠTAVANJA U SKLADU SA EU DIREKTIVAMA
}

\author{
Selim Lika ${ }^{1}$, Nebojša Jeremić ${ }^{3}$ \\ ${ }^{1}$ Consulate General of Montenegro, 801 2nd Ave, Suite 7, New York, NY 10017, United States, selimlika@gmail.com \\ ${ }^{2}$ Telekom Srbija a.d. Funkcija za internu reviziju, Takovska 2, Beograd, Srbija, nebojsaje@telekom.rs
}

Apstrakt:
Postizanje ciljeva Evropske Unije u smanjenju emisija sa efektom staklene bašte će biti veliki izazov
za sve zemlje članice i njihove privatne sektore. Dugoročni cilj smanjenja emisije od 80 do $95 \%$ do
2050. godine sa 1990. kao baznom godinom će zahtevati od svih učesnika da urade svoj deo. Tre-
nutno, regulatorni i tržišni pritisci utiču na kompanije da izveštavaju o emisijama i predlažu mere
smanjenja istih. Ipak, u mnogim slučajevima, ceo proces se vrši na dobrovoljnoj osnovi. Imajući u
vidu izvor emisija, privatne kompanije će morati da budu lideri u ovom procesu. Sa uvođenjem stro-
žeg regulatornog okvira, mnoge korporacije će se suočiti sa izazovima prilagođavanja na promene.

\section{Ključne reči:}

ekološko izveštavanje, nisko-karbonski razvoj, korporativno izveštavanje, karbonski ograničena privreda; 